\title{
Petroleum geochemical characteristics of dark mudstone of Taiyuan formation in Liuzigou area, Jinci county, Shanxi Province
}

\author{
GAOCHAO CHEN $^{1 *}$, JUNLIN ZHOU ${ }^{2}$ \\ ${ }^{1}$ Xi'an Center of China Geological Survey/ Northest China \\ Center for Geoscience Innovation, Xi'an 710054, Shaanxi, \\ China ("correspondence: sxxycc08@163.com) \\ ${ }^{2}$ Xi'an Center of China Geological Survey/ Northest China \\ Center for Geoscience Innovation, Xi'an 710054, Shaanxi, \\ China (zjlcug@163.com)
}

The late Paleozoic Taiyuan formation in liuzigou area of Taiyuan basin was mainly constructed by interlacing coalbearing sand and mudstone with carbonate rock. Tidal flat facies - bay lagoon facies and swamp facies developed dark mudstone and the thickness of dark mudstone is $16.54 \mathrm{~m}$. Oil and gas geological evaluation was carried out according to the mudstones of tidal flat facies - bay lagoon facies and coastal marsh facies. The results showed that organic carbon (TOC), chloroform asphalt "A" and hydrocarbon potential S1+S2 of tidal flat facies - bay lagoon facies were $0.53 \sim 2.57 \%$ (average 1.21\%), $0.002 \sim 0.004 \%, 0.05 \sim 0.27 \mathrm{mg} / \mathrm{g}$ (average $0.118 \mathrm{mg} / \mathrm{g}$ ), respectively. The organic carbon (TOC), chloroform asphalt "A" and hydrocarbon potential S1+S2 of Dark mudstone of swamp facies were $1.24 \sim 4.93 \%$ (average $2.60 \%$ ), $0.004 \%, 0.09 \sim 0.48 \mathrm{mg} / \mathrm{g}$ (average $0.182 \mathrm{mg} / \mathrm{g}$ ), respectively. Components of kerogen type identification of dark mudstone $\mathbb{I}$, belongs to the humic type; Organic matter maturity (Ro) is $1.55 \sim 1.60$, which is a highly mature source rock. According to the TOC content evaluation, it should be a good source rock, but chloroform asphalt "A" and hydrocarbon generation potential shows it is a very poor source rock, which may be related to the high maturity of mudstone. The TOC content of mudstone of swamp facies is obviously higher than that of tidal flat facies and bay lagoon facies. The samples of argillaceous rocks have higher organic matter abundance and maturity, which can be used as the better source rocks of the upper Paleozoic. Shore-bog mudstone is better than tidal flat - bay lagoon mudstone. Therefore, the exploration of natural gas in Taiyuan basin and surrounding area should be strengthened. 